Article

\title{
Economic and Spatial Determinants of Energy Consumption in the European Union
}

\author{
Jorge Flores-Chamba ${ }^{1}\left(\mathbb{D}\right.$, Michelle López-Sánchez ${ }^{1}{ }^{\circledR}$, Pablo Ponce $^{1}{ }^{1}$, \\ Patricia Guerrero-Riofrío ${ }^{1}$ and José Álvarez-García ${ }^{2, *(D)}$ \\ 1 Macroeconomics and Economic Policy Research Line, School of Economics, Universidad Nacional de Loja, \\ Loja 110150, Ecuador; jorge.flores@unl.edu.ec (J.F.-C.); michelle.lopez@unl.edu.ec (M.L.-S.); \\ pablo.ponce@unl.edu.ec (P.P.); patricia.y.guerrero@unl.edu.ec (P.G.-R.) \\ 2 Financial Economy and Accounting Department, Faculty of Business, Finance and Tourism, \\ University of Extremadura, 10071 Caceres, Spain \\ * Correspondence: pepealvarez@unex.es; Tel.: +34-927-257-968
}

Received: 21 September 2019; Accepted: 24 October 2019; Published: 28 October 2019

check for updates

\begin{abstract}
In recent decades, various policies have been implemented to reduce energy consumption, as well as a considerable increase in research that analyzes the determinants of energy consumption, both with a standard feature, mitigating environmental degradation. However, few studies investigate the economic and spatial determinants of energy consumption in the European Union (EU). Therefore, to cover the knowledge gap, based on the review of the existing literature, this document is designed to analyze the determinants and energy policy in energy consumption in the EU. For this reason, the objective of this research is to analyze the effect of human capital, the price of oil, and Kyoto Protocol policy on energy consumption. In addition, the effect of contiguity and spatial concentration on energy consumption is studied for 34 European countries, of which 26 belong to the EU, for the period 2000-2016. For this, data collected from the World Bank (2017) and the World Energy Statistical Review (2017) were used. The work methodology is based on the application of econometric techniques for panel data, and spatial econometrics, based on the application of a Spatial Durbin Model (SDM), through which the existence of "spillovers" was determined in the implementation of the energy policy. The results of the estimates show a negative effect of the price of oil and human capital concerning energy consumption, and the variable "Policy" reflects a reduction in the energy consumption of the EU countries in the period analyzed. Additionally, the space panel confirms that the behavior of a country's energy consumption depends on its past values and the level of consumption presented by its neighbors, corroborating the importance of territorial contiguity in the success of environmental policy in the case of the European Union.
\end{abstract}

Keywords: energy consumption; human capital; spatial econometrics; oil price

\section{Introduction}

In recent years there has been a downward trend in energy consumption in European countries, associated with the growing consumption of renewable energy to counteract pollution [1]. According to the European Environment Agency, overall consumption was reduced by more than $10 \%$ in the period 2005-2015, mainly as a result of two factors: An increase in energy efficiency, and the implementation of energy policies in countries. Regarding the first one, empirical evidence reveals that one of the main determinants in the development of this factor is human capital. Researchers such as Salim, Yao, and Chen [2], Shahbaz, Gozgor, and Hammoudeh [3], and Coers and Sanders [4] show that an increase in human capital contributes to reducing energy consumption. Another variable to consider within this factor is the price of energy. Authors such as Humbatova and Qadim-Oglu Hajiyev [5] 
establish that it is a predominant element in the world economy. In this sense, dependence on fossil fuels, especially oil, still prevails as the main source of supply. There are several studies that reveal the existence of a negative relationship between the oil price and energy consumption, and authors such as Moshiri [6], Moshiri and Martínez Santillán [7], and Sarkodie and Adom [8] confirm it.

The second factor that influences the reduction of energy consumption in Europe is associated with the implementation of energy policies. The European Union (EU) has been promoting the reduction of carbon emissions and within the framework of the Kyoto Protocol of the United Nations on climate change, which was adopted in 1997, but which came into force as of 2005. "It undertook to reduce its average total emissions during the period 2008-2012 by 8\% compared to 1990" [9], taking into account that in the last decades, the reform of the EU energy markets has produced positive results, and market liberalization stimulates energy efficiency [10]. In this same framework, the "20-20-20" measure was established, which aims to reduce primary energy consumption of the European Union by $20 \%$; to reduce greenhouse gas emissions by $20 \%$; and to increase the contribution of renewable energies to $20 \%$ of consumption.

In this context, the main objective of this research is to analyze the effect of human capital, the price of oil, and Kyoto Protocol policy on energy consumption. In addition, it studies the effect of contiguity and spatial concentration on Europe's energy consumption under the hypothesis that an energy saving policy that is having a greater effect in the European Union justifies more control throughout Europe. For this, 34 European countries were selected as a sample, of which 26 belong to the European Union during the period 2000-2016. Data were collected from the Statistics Review of World Energy [11] and the World Bank [12].

The methodology to follow is econometric modelling, which includes three types of regressions. The first one is a basic regression for panel data in which the dependent variable is represented by energy consumption, and the independent variables are human capital and the oil price. The second regression, based on the Generalized Least Squares (GLS) procedure, is basically the same, but now the following are included as control variables: Gross value added in agriculture, gross value added in industry, gross value added in services, employment in agriculture, employment in industry, employment in services, and research and development (R\&D) expenditure. In addition, to determine the impact of the energy saving policy in the European Union, a dichotomous variable is included, that assigns the value of " 1 " to countries that are part of this Union and " 0 " to those that are not part of it, called "Policy". The third regression includes spatial econometric modelling, based on the application of the Spatial Durbin Model (SDM), developed by Anselin [13]; it is a dynamic spatial panel for fixed effects, whereby the existence of "spills" or "spillovers" in the implementation of the energy policy are determined, considering the spatial behavior of the explanatory variables. The regression includes the variables of the two aforementioned models, except for the "Policy" variable and the control variables: Gross value added and employment in agriculture, the latter not being statistically significant in the modelling.

In this context, this research aims to provide empirical evidence on the impact of the energy saving policy in the European Union and the effect of spatial dependence on energy consumption, and to determine the existence or not of positive externalities in the implementation of the energy policy of the European Union, unlike the literature that studies the effect of the oil price and human capital on energy consumption [14-17].

The previous literature in relation to energy consumption is varied. However, there is a lack of studies that analyze the role of human capital on energy consumption at macro level [2]. Furthermore, according to Shahbaz, Gozgor, and Hammoudeh [3], previous empirical evidence studies did not consider human capital as a determinant of energy demand in developed countries, as is the case in most European countries, specifically the European Union (EU). In addition, several studies have focused on analyzing the effect of oil prices on energy consumption since the oil crisis in 1970 [18], considering the price of oil as one of the main determinants of demand for energy [3]. 
According to previous studies conducted, there are several studies that define as determinants of energy demand, education $[14,15,19,20]$ and the energy price [16-18,21-23]. It is worth mentioning that there are few studies that analyze the effect of these two variables on energy consumption using a spatial methodology with panel data for European countries, especially of the EU, in the context of evaluating the energy saving policy of Kyoto in 2008. Therefore, this work is an important contribution to the scientific energy field.

Finally, it is essential to note that authors such as Ing, Liao, and Huang [24]; Li and Wu [25]; Lv, Chen, and Cheng [26]; and Shurui, Jingyou, Lei, and Zhong [27], use space econometric models, including the Durbin model, to investigate the impact of different policy mechanisms on economic variables at the sector level. At the same time, with its purpose, they have been able to determine the effects of overflow and spatial autocorrelation, which have served as a guide to suggest regional and sectoral policies. In agreement with LeSage and Pace [28], which mentions that the Space Durbín Model can capture the spatial correlation of dependent variables and the effects of the spatial overflow of independent variables. In this sense, the importance of the spatial econometric method of the present article lies in the estimation of the existing spillovers in the implementation of the environmental policy in the European Union in the analyzed period, that is, the positive effects of generation of joint and coordinated implementation of environmental policy for a set of countries.

The structure of the work is as follows. After the introduction, in the second section, the empirical evidence is presented, where studies related to the research topic are reviewed. The methodology is presented in the third section. The fourth section collects the results and their discussion. Finally, the main conclusions are highlighted in the last section.

\section{Review of Previous Literature}

The quality of the environment is directly related to energy consumption, according to Akadiri, Bekun, and Sarkodie [29], since energy is the central resource used in various economic activities, according to Bekun, Emir, and Sarkodie [30], and Destek and Sarkodie [31]. Therefore, the importance of knowing the determinants of energy consumption in the EU in which studies such as Bekun, Alola, and Sarkodie [32] confirm that energy consumption triggers environmental pollution in this region. Some studies analyze energy consumption factors, in this research, empirical evidence on the relationship between energy consumption and its determining variables is classified in two large groups. The first one includes those studies that examine the relationship between human capital and energy consumption, since the population is a factor that affects energy consumption [33]. The work of Fang and Chang [34] is the first one to analyze the role of human capital in the relationship of energy and income, in its study of 16 countries in the region of Asia and the Pacific, applying FMOLS (Fully Modified Least Squares), and they find that human capital produces a one-way energy consumption. Likewise, Shahbaz, Gozgor, and Hammoudeh [3], through the application of an Autoregressive Distributive Lag (ARDL), take this approach for the US economy, and find a long-term relationship in which a $1 \%$ increase in education reduces energy consumption by $0.1095 \%$. In this same line is Salim, Yao, and Chen [2], whose study for China finds a negative relationship, which states that an increase of $1 \%$ in human capital causes a decrease in energy consumption between $0.18 \%$ and $0.45 \%$, which could be attributed to a greater accumulation of human capital after schooling education.

In contrast, for China, Li and Lin [35], when applying an FMOLS model during 1999-2013, mention that in addition to education, many energy consumption practices are generated and developed through job training, experience, and learning through practice, instead of being taught explicitly in the classroom. Coers and Sanders [4], in a panel for 30 countries of the OECD (Organization for Economic Cooperation and Development) find a short-term relationship between energy consumption and human capital during 1960 and 2000. Huang, Hwang, and Yang [36] also observed a short-term relationship between human capital and energy consumption by applying a VAR model (Vector Autoregression) for a panel of 82 countries worldwide, classified by their income level. Similarly, Salim, 
Hassan, and Shafiei [37] find a short-term equilibrium relationship between energy consumption and human capital by using panel data co-integration techniques.

Regarding the growth level of countries, Inglesi-Lotz and del Corral Morales [38], in their analysis for a group of developed and developing countries in the period 1980-2013, observed the existence of a unidirectional relationship from education towards consumption. In addition, they indicate that energy consumption increases with higher levels of education in developing countries, compared to developed countries, where energy consumption decreases with higher levels of education. Pablo-Romero and Sánchez-Braza [39], from a geographical point of view, use panel data from 38 countries for the 1995 to 2007 period, observing a high substitutability level between human capital and energy consumption.

The second group of research examines the oil price as a determinant of energy consumption, since according to Huntington [40], the oil price is one of the main determinants of energy demand. Authors such as Moshiri [6], and Moshiri and Martínez Santillán [7], support this statement and establish that the reduction of energy consumption, due to an increase in its price, depends on the household income level. In the same vein, we find the works of Sarkodie and Adom [8], which by using the NIPALS method (Non-Linear Iterative Partial Least Squares) show that the energy price favors reducing its consumption. Valizadeh, Sadeh, Javanmard, and Davodi [41] analyze petrochemical energy consumption in Iran through the application of an ARDL model (Autoregressive model with Distributed Delays). The results show a significant effect on energy consumption regarding its price. With the same methodology, Shahbaz, Gozgor, and Hammoudeh [3], indicate that the energy price and energy consumption are co-integrated in the long term, and increases in the energy price lead to a decrease in demand.

Regarding the most developed countries, Lee and Chiu [42] analyzed 24 OECD countries through a PSECM panel (Panel Smooth transition regression model with the error-correction term), finding that the energy price and energy consumption are co-integrated in the long term. Similarly, Gately and Huntington [43], for 96 economies around the world, found that the energy consumption of the OECD countries is more sensitive to increases than decreases in energy prices. Thus, Bentzen and Engsted [44], in their study in Denmark for the period 1948-1990, using co-integration and error correction methods, observed a significant negative effect on energy consumption, caused by an increase in the oil price. In contrast, the study by Yuan, Liu, and Wu [45], who define the hypothesis that an increase in the energy price will decrease the consumption of industrial sectors in the long term, but in the short term it will increase. The study carried out by Labandeira, Labeaga, and López-Otero [46] is different from the aforementioned studies, which through a meta-analysis of studies since 1970, considers that there is an inelastic demand for energy consumption related to energy prices.

Finally, there is a set of studies, mainly for Chinese regions, where the spatial "spills" of the secondary or manufacturing industry in energy consumption are analyzed from a spatial perspective. In this context, the works of Jiang, Folmer, and Ji [47], Huang, Du, and Hao [48], Jiang, Folmer, Ji, and Zhou [49], and Han, Xie, and Fang [50] stand out, where it is evident that an increase in the participation of the secondary sector in the total production of these regions caused an increase in energy consumption in the period 2000-2017; and of Hao and Peng [51], where an increase in such participation did not contribute significantly to energy savings. Similarly, Liu, Lin, Hu, Lu, and Cai [52], mention that energy consumption in the East of China is affected by the energy consumption of the Central Region of China. In addition, Jiang, Folmer, Ji, and Zhou [49], through the estimation of a spatial panel for 29 Chinese provinces in the period 2003-2015, found evidence that the savings or reduction of energy consumption shows a spatial autoregressive process. Finally, in Huang, Du, and Hao [48], it was observed that an increase in the energy price produced an increase in energy consumption in the period 2000-2014, considering a spatial approach. 


\section{Data and Methodology}

\subsection{Data}

The data used in this research is obtained from two information sources: From the Statistical Review of World Energy [11] and the World Bank [12]. Panel data are used for 34 countries in Europe (26 belong to the European Union) and economic variables are considered to estimate econometric models, during the period 2000-2016. In all the regressions, the dependent variable is represented by energy consumption, and the independent variables are human capital and the oil price. In addition, the following are used as control variables: Gross value added in agriculture, gross value added in industry, gross value added in services, employment in agriculture, employment in industry, employment in services, and research and development (R\&D) expenditure. In research, such as Bentzen and Engsted [44], Huang, Hwang, and Yang [36], Huntington [40], Pirlogea and Cicea [53], Coers and Sanders [4], Lee and Chiu [42], Salim, Hassan, and Shafiei [37], Pablo -Romero and Sánchez-Braza [39], Moshiri [6], Gately and Huntington [43], Fang and Chang [34], Salim, Yao, and Chen [2], Inglesi-Lotz and del Corral Morales [38], Wang and Nie [18], Shahbaz, Gozgor, and Hammoudeh [3], Moshiri and Martínez Santillán [7], Sarkodie and Adom [8], and Beșir and Aldea [54], similar variables were used. All the variables were converted into logarithms in order to eliminate the heterogeneity in the econometric analysis (except human capital) (Table 1).

Table 1. Definition of the variables.

\begin{tabular}{|c|c|}
\hline Variables & Definition \\
\hline Log (Energy consumption) & Primary energy consumption (Kilogram of oil equivalent per capita). \\
\hline Policy & $\begin{array}{l}\text { Primary energy savings that takes values of " } 1 \text { " if it belongs to the EU } \\
\text { and " } 0 \text { " if not. }\end{array}$ \\
\hline Human capital & Years of schooling of the population. \\
\hline Log (Oil price) & Price of oil barrel, at constant prices of 2017 US \$. \\
\hline Log (Value added in agriculture) & Value added in agriculture, at constant prices of 2010 US \$. \\
\hline Log (Value added in industry) & Value added in industry, at constant prices of 2010 US \$. \\
\hline Log (Value added in services) & Value added in services, at constant prices of 2010 US \$. \\
\hline Log (Employment in agriculture) & Percentage of employment in agriculture of total employment. \\
\hline Log (Employment in industry) & Percentage of employment in industry of total employment. \\
\hline Log (Employment in services) & Percentage of employment in services of total employment. \\
\hline Log (Research and Development) & $\begin{array}{l}\text { Activities undertaken to increase the flow of scientific and technical } \\
\text { knowledge (constant } 2010 \text { US \$). }\end{array}$ \\
\hline
\end{tabular}

Source: Data and specifications of the World Bank [12].

Considering that one of the objectives of this article is to analyze the effect of contiguity and spatial concentration on energy consumption in Europe, the behavior of the main variables is also analyzed from a spatial perspective. Figure 1 shows that those European countries with the highest level of human capital, represented by the largest yellow circles, have a low energy consumption level, represented by the less intense color on the map. On the other hand, Figure 2 shows the evolution of energy consumption and the oil price in Europe. 


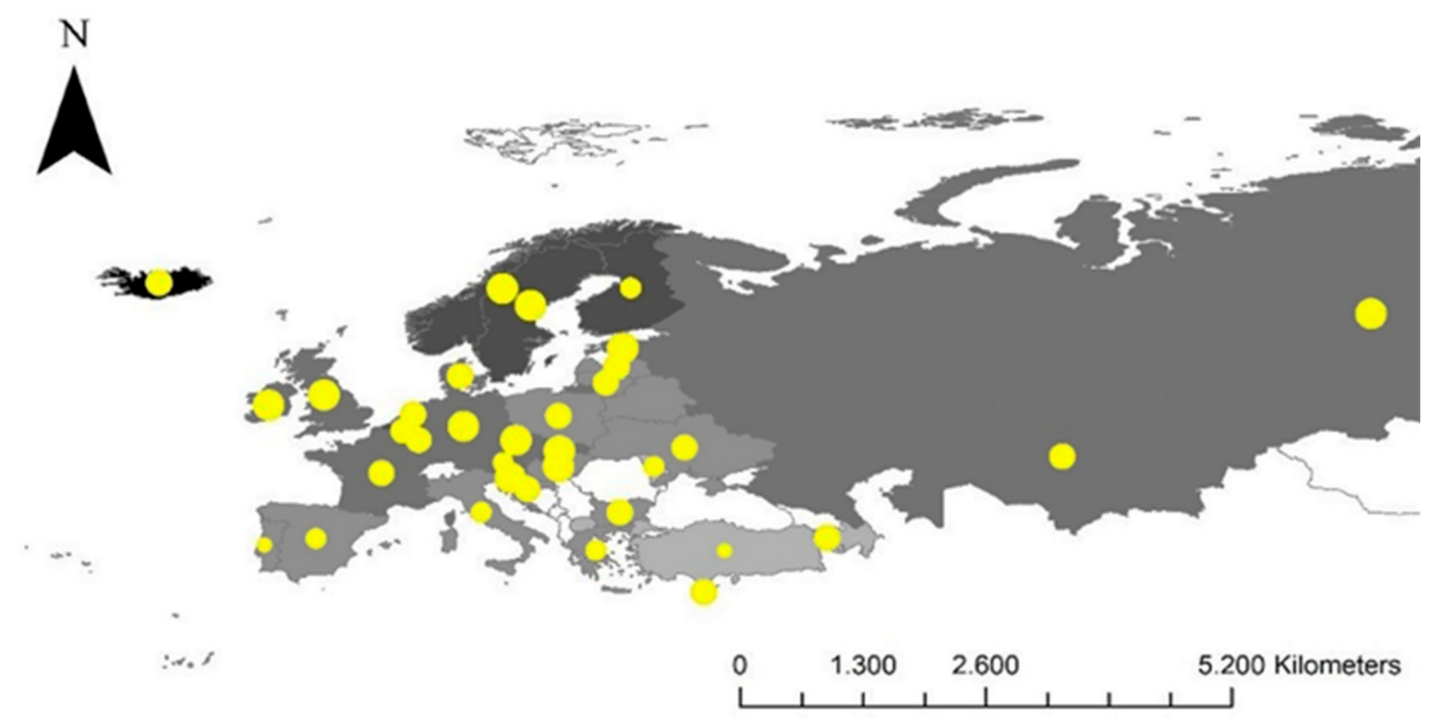

\section{Energy consumption Human capital}

\begin{tabular}{|ll|}
\hline & No data \\
$0,01-1462,28$ & no data \\
\hline $1462,29-2905,94$ & $0,01-7,49$ \\
\hline $2905,95-4738,90$ & $7,50-10,16$ \\
\hline $4738,91-8048,13$ & $10,17-11,26$ \\
\hline $8048,14-14614,55$ & $11,27-12,78$ \\
\hline
\end{tabular}

Figure 1. Relationship between energy consumption and human capital in Europe.

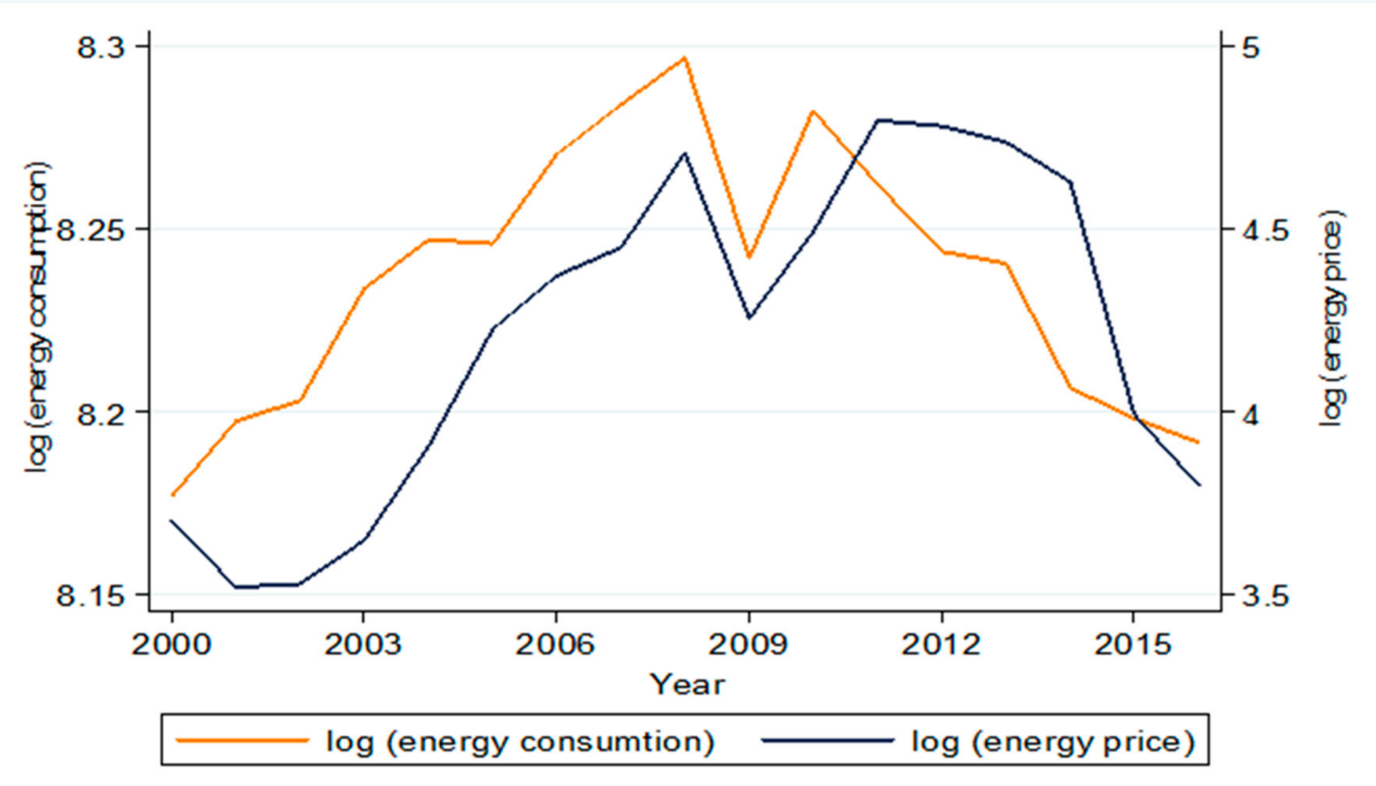

Figure 2. Evolution of energy consumption and oil price in Europe.

Finally, Table 2 shows the main descriptive statistics of the dependent variable, the independent variables, and the control variables, among them: the mean, the standard deviation, the minimum and maximum values, and the total number of observations. 
Table 2. Descriptive statistics of the variables.

\begin{tabular}{|c|c|c|c|c|c|c|}
\hline \multicolumn{2}{|l|}{ Variable } & \multirow{4}{*}{$\begin{array}{c}\text { Mean } \\
8.080203\end{array}$} & \multirow{4}{*}{$\begin{array}{l}\text { Std. Dev. } \\
0.5538243 \\
0.5524187 \\
0.1000853\end{array}$} & \multirow{4}{*}{$\begin{array}{c}\text { Min. } \\
6.427251 \\
6.75565 \\
7.619505\end{array}$} & \multirow{4}{*}{$\begin{array}{c}\text { Max. } \\
9.807975 \\
9.564859 \\
8.341815\end{array}$} & \multirow{4}{*}{$\begin{array}{c}\mathbf{N} \\
\mathrm{N}=578 \\
\mathrm{n}=34 \\
\mathrm{~T}=17\end{array}$} \\
\hline & Overall & & & & & \\
\hline Log (Energy & Between & & & & & \\
\hline & Within & & & & & \\
\hline \multirow{3}{*}{ Human capital } & Overall & 10.78649 & 1.324494 & 6.1 & 13.70181 & $\mathrm{~N}=578$ \\
\hline & Between & & 1.214325 & 6.861587 & 12.77734 & $\mathrm{n}=34$ \\
\hline & Within & & 0.5662041 & 8.912348 & 13.44276 & $\mathrm{~T}=17$ \\
\hline \multirow{3}{*}{ Log (Oil price) } & Overall & 4.208679 & 0.44449427 & 3.521414 & 4.797749 & $\mathrm{~N}=578$ \\
\hline & Between & & 0 & 4.208679 & 4.208679 & $\mathrm{n}=34$ \\
\hline & Within & & 0.4449427 & 3.521414 & 4.797749 & $\mathrm{~T}=17$ \\
\hline \multirow{3}{*}{ UE } & Overall & 0.7647059 & 0.4245499 & 0 & 1 & $\mathrm{~N}=578$ \\
\hline & Between & & 0.4305615 & 0 & 1 & $\mathrm{n}=34$ \\
\hline & Within & & 0 & 0.7647059 & 0.7647059 & $\mathrm{~T}=17$ \\
\hline \multirow{3}{*}{$\begin{array}{l}\text { Log (Value added in } \\
\text { agriculture) }\end{array}$} & Overall & 22.22418 & 1.447231 & 18.44183 & 25.141 & $\mathrm{~N}=578$ \\
\hline & Between & & 1.460601 & 18.91101 & 24.90293 & $\mathrm{n}=34$ \\
\hline & Within & & 0.1424082 & 21.71601 & 23.02636 & $\mathrm{~T}=17$ \\
\hline \multirow{3}{*}{$\begin{array}{l}\text { Log (Value added in } \\
\text { industry) }\end{array}$} & Overall & 24.48103 & 1.74011 & 20.30617 & 27.68176 & $\mathrm{~N}=578$ \\
\hline & Between & & 1.756646 & 20.56688 & 27.54817 & $\mathrm{n}=34$ \\
\hline & Within & & 0.1665738 & 23.81526 & 25.15466 & $\mathrm{~T}=17$ \\
\hline \multirow{3}{*}{$\begin{array}{c}\text { Log (Value added in } \\
\text { services) }\end{array}$} & Overall & 25.39299 & 1.759867 & 21.00189 & 28.47332 & $\mathrm{~N}=578$ \\
\hline & Between & & 1.77704 & 21.77784 & 28.37365 & $\mathrm{n}=34$ \\
\hline & Within & & 0.1637854 & 24.61704 & 25.8756 & $\mathrm{~T}=17$ \\
\hline \multirow{3}{*}{$\begin{array}{l}\text { Log (Employment } \\
\text { in agriculture) }\end{array}$} & Overall & 1.827805 & 0.9113976 & 0.0953102 & 3.756538 & $\mathrm{~N}=578$ \\
\hline & Between & & 0.9049958 & 0.2440247 & 3.648656 & $\mathrm{n}=34$ \\
\hline & Within & & 0.1853086 & 1.375283 & 2.3399934 & $\mathrm{~T}=17$ \\
\hline \multirow{3}{*}{$\begin{array}{l}\text { Log (Employment } \\
\text { in industry) }\end{array}$} & Overall & 3.228002 & 0.2445035 & 2.332144 & 3.703768 & $\mathrm{~N}=578$ \\
\hline & Between & & 0.2275576 & 2.709302 & 3.66466 & $\mathrm{n}=34$ \\
\hline & Within & & 0.097136 & 2.850844 & 3.591393 & $\mathrm{~T}=17$ \\
\hline \multirow{3}{*}{$\begin{array}{l}\text { Log (Employment } \\
\text { in services) }\end{array}$} & Overall & 4.151188 & 0.1849056 & 3.427515 & 4.48074 & $\mathrm{~N}=578$ \\
\hline & Between & & 0.1790478 & 3.604715 & 4.416045 & $\mathrm{n}=34$ \\
\hline & Within & & 0.0549631 & 3.971507 & 4.311132 & $\mathrm{~T}=17$ \\
\hline \multirow{3}{*}{$\begin{array}{l}\text { Log (Research + } \\
\text { Development) }\end{array}$} & Overall & 21.40826 & 2.161992 & 15.81353 & 25.77943 & $\mathrm{~N}=578$ \\
\hline & Between & & 2.172433 & 16.81423 & 25.20842 & $\mathrm{n}=34$ \\
\hline & Within & & 0.292599 & 20.38957 & 23.54424 & $\mathrm{~T}=17$ \\
\hline
\end{tabular}

\subsection{Econometric Strategy}

The study was carried out with panel data for the 34 European countries analyzed during the period 2000-2016, with the purpose of analyzing the effect caused by human capital and the oil price on energy consumption. The econometric strategy was divided into two parts.

In the first part, with supporting panel data, regressions were made in order to verify the degree of association and the statistical and economic relationship of the variables in the 34 countries analyzed. Equation (1) determines the relationship between the dependent variable and the independent variables:

$$
\log (c e \mid i t)=\beta_{0}+\beta_{1} c h_{i t}+\beta_{2} \log \left(p p_{i t}\right)+\varepsilon_{i t}
$$

where $\log (c e \mid i t)$ represents energy consumption, $c h_{i t}$ is human capital, $\log \left(p p_{i t}\right)$ is the oil price, and $\varepsilon_{i t}$ is the error term. The subscript $i t$ refers to countries $i=1,2,3, \ldots, 34$, and to each of the years analyzed $t=2000,2001,2002, \ldots, 2016$.

Next, the Hausman test [55] was applied, which suggests that there is a systematic difference of the estimators of fixed and random effects $\left(\gamma_{F E}-\gamma_{\mathfrak{R}}\right)$ and statistically different from 0 . This is constituted 
as evidence in favor of the use of a panel model for fixed effects. To determine the suitability of the model used, the Wooldridge autocorrelation tests [56], Wald heteroscedasticity [57], and Friedman's cross-section dependence were additionally performed. Given the existence of heteroscedasticity and cross-section dependence, the Generalized Least Squares (GLS) procedure is used, which is a more efficient extension of the Ordinary Least Squares (OLS), in the case of heteroscedasticity and autocorrelation problems.

Finally, to give the model greater consistency, the control variables were incorporated, obtaining Equation (2).

$$
\log (c e \mid i t)=\beta_{0}+\beta_{1} c h_{i t}+\beta_{2} \log \left(p p_{i t}\right)+\beta_{3}\left(p o l_{i t}\right)+\beta_{4} \log \left(Z_{i t}\right)+\varepsilon_{i t}
$$

where $\log (c e \mid i t)$ represents energy consumption; $c h_{i t}$ is human capital; $\log \left(p p_{i t}\right)$ is the oil price; $\left(p o l_{i t}\right)$ is the dummy variable that reflects the effect of the implementing the energy saving policy for European Union countries; $\log \left(Z_{i t}\right)$ represents all the control variables: Gross value added in agriculture, gross value added in industry, gross value added in services, employment in agriculture, employment in industry, employment in services, and research and development (R\&D) expenditure; and $\varepsilon_{i t}$ is the error term.

In the second part, to capture the effect of the spatial dependency detected, spatial econometric modelling was used, which is based on the application of a Spatial Durbin Model (SDM), developed by Anselin [13]. It is a mixed cross-regression autoregressive mixed model of spatial regression, similar to time series models, which contains the spatial autoregressive model (SAR), and also includes the spatial lag of independent variables (LeSage and Pace [28]).

Following LeSage and Pace [28], Equation (3) includes the formulation of the SDM model to be estimated in this paper:

$$
\log (c e \mid i t)=\beta_{0}+\beta_{1} c h_{i t}+\beta_{2} \log \left(p p_{i t}\right)+\beta_{3} \log \left(Z_{i t}\right)+w \log \left(c e_{i t}\right)+w \log \left(X_{i t}\right)+\varepsilon_{i t}
$$

where $\log (c e \mid i t)$ represents energy consumption; $c h_{i t}$ is human capital; $\log \left(p p_{i t}\right)$ is the oil price; $\log \left(Z_{i t}\right)$ represents all the control variables: Gross value added in agriculture, gross value added in industry, gross value added in services, employment in agriculture, employment in industry, employment in services, and research and development $(R \& D)$ expenditure; $w$ is the square matrix of the so-called "queen" spatial "weights", which considers those countries that share at least one point of their geographical border as neighbors (assigning the value of " 1 " to those countries and " 0 " to the rest); $w \log \left(c e_{i t}\right)$ is the spatial lag of the energy consumption dependent variable; $w \log \left(X_{i t}\right)$ represents the spatial lag of the matrix of independent and control variables; and $\varepsilon_{i t}$ is the error term.

\section{Results}

The panel model has been estimated by fixed effects, considering both the temporal dimension and the cross-sectional dimension, for the total number of countries (Total), for the countries of the European Union (EU), and for countries that are not part of the European Union (NUE). The validity of the model was verified by the Hausman test [55] and the statistical significance of the coefficients of the dummies corresponding to the two dimensions of the panel initially mentioned (Table 3).

Table 3 shows that energy consumption in Europe (Total) and in the European Union (EU) depends negatively on human capital, a $1 \%$ increase in human capital generates a reduction in energy consumption by $0.027 \%$ in Total and $0.0291 \%$ in the EU. These results coincide with the works of Shahbaz, Gozgor, and Hammoudeh [3], Salim, Yao, and Chen [2], Li and Lin [35], who highlight the existence of an indirect relationship between energy consumption and human capital. Inglesi-Lotz and del Corral Morales [38] also make a classification between developing and developed countries, highlighting the negative relationship between the variables mentioned for this last group, unlike what happens in developing countries, where a positive relationship is established, similar to the results we obtained for countries that are not part of the European Union (NEU), in which an increase of $1 \%$ of human capital causes an increase of $0.135 \%$ of energy consumption. 
Table 3. Results of the panel estimate by fixed effects (main variables).

\begin{tabular}{cccc}
\hline Variables & Total & EU & NEU \\
\hline Human capital & $-0.0270^{*}$ & $-0.0291^{* * *}$ & $0.135^{*}$ \\
& $(-2.20)$ & $(-3.13)$ & $(2.44)$ \\
Oil price & 0.102 & -0.321 & 0.357 \\
& $(0.46)$ & $(-1.92)$ & $(0.44)$ \\
Constant & $6.621^{* * *}$ & $9.702^{* * *}$ & 3.939 \\
& $(9.16)$ & $(17.28)$ & $(1.56)$ \\
Chis square (p-value) & 0.0000 & 0.0000 & 0.0000 \\
Serial correlation test (p-value) & 0.8129 & 0.6944 & 0.8260 \\
Cross-sectional independence (p-value) & 0.0000 & 0.0000 & 0.2244 \\
Fixed effects (time) & YES & YES & YES \\
Fix effects (country) & YES & YES & YES \\
Observations & 578 & 442 & 136 \\
\hline
\end{tabular}

Notes: $t$ statistics in parentheses ${ }^{*} p<0.05,{ }^{* *} p<0.01,{ }^{* * *} p<0.001$.

Regarding the oil price, one of the main determinants of energy consumption, according to Wang, $\mathrm{Su}, \mathrm{Li}$, and Ponce [58], Sarkodie and Adom [8], Valizadeh, Sadeh, Javanmard, and Davodi [41], Shahbaz, Gozgor, and Hammoudeh [3], Gately and Huntington [43], and Bentzen and Engsted [44], which coincides in stating that the price of energy has a negative impact on energy consumption, particularly in this case that relationship is met, and the variable is statistically significant (at a level of significance of $10 \%$ ), but only in the case of countries of the European Union. An increase of $1 \%$ in the price of oil generates a reduction of $0.321 \%$ of energy consumption in this group of countries.

Once the model was estimated, diagnostic tests were performed to validate the robustness and reliability. Specifically, the autocorrelation tests of Wooldridge [56], Wald's heteroscedasticity [57], and Friedman's cross-sectional dependence (ideal for panels with $\mathrm{N}>\mathrm{T}$ ) were performed. The corresponding p-values indicate that the estimation in Table 3 shows some "problems" of autocorrelation, heteroscedasticity, and cross-section dependence, mainly for the complete panel (Total) and for that of European Union countries (EU). Wooldridge [59] points out that there are "robust to heteroscedasticity" methods that generate statistics that work regardless of the type of heteroscedasticity present in the population analyzed and that also consider the presence of serial autocorrelation, specifically recommending the use of Generalized Least Squares (GLS), given the inability of OLSs to generate unbiased and consistent estimators, in the presence of these problems. Table 4 shows the results of this type of estimate for the case of this work.

The results in Table 3 provide an initial approximation of Europe's behavior regarding energy consumption. However, to determine the impact of the energy saving policy on the European Union, a dichotomous variable that assigned the value of " 1 " to those countries that are part of this Union was included in the estimation by GLS shown in Table 4 and " 0 " to those countries that are not part of it, along with the rest of the control variables. There is evidence that the "Policy" variable is statistically significant and indicates that European Union countries have, in fact, reduced their consumption level in the period 2000-2016 (given the negative sign of the variable). The "human capital" variable is not statistically significant.

On the other hand, the oil price is statistically significant and of a negative sign. An increase in the oil price by $1 \%$ generates a decrease of $1.316 \%$ in energy consumption. Finally, the gross value added in industry (manufacturing), the gross value added in services, employment in industry, and employment in services show a statistically significant and positive relationship with energy consumption: An increase of $1 \%$ of each of these variables produces an increase of $0.128 \%, 0.306 \%$, $0.259 \%$, and $0.243 \%$, respectively, of energy consumption in the European countries analyzed. In summary, the oil price generates a decrease in the use of energy in Europe, as opposed to the gross value added and employment in industry and services, whose increases increase energy consumption in the countries analyzed. 
Table 4. Results of the panel estimate (complete) for fixed effects (Evaluation of energy efficiency policy plus control variables).

\begin{tabular}{|c|c|}
\hline Variables & GLS \\
\hline Policy & $\begin{array}{c}-1.311^{* * *} \\
(-5.40)\end{array}$ \\
\hline Human capital & $\begin{array}{c}-0.0100 \\
(-1.13)\end{array}$ \\
\hline Oil price & $\begin{array}{c}-1.316^{* * *} \\
(-5.11)\end{array}$ \\
\hline Value added in agriculture & $\begin{array}{c}-0.00161 \\
(-0.11)\end{array}$ \\
\hline Value added in industry & $\begin{array}{c}0.128^{* * *} \\
(4.25)\end{array}$ \\
\hline Value added in services & $\begin{array}{c}0.306^{* * *} \\
(6.57)\end{array}$ \\
\hline Employment in agriculture & $\begin{array}{c}0.0251 \\
(1.29)\end{array}$ \\
\hline Employment in industry & $\begin{array}{c}0.259 * * * \\
(4.92)\end{array}$ \\
\hline Employment in services & $\begin{array}{c}0.243^{* *} \\
(2.30)\end{array}$ \\
\hline Research + Development & $\begin{array}{c}-0.00706 \\
(-0.77)\end{array}$ \\
\hline Constant & $\begin{array}{l}0.734 \\
(0.88)\end{array}$ \\
\hline Chis square (p-value) & 0.0000 \\
\hline Serial correlation test ( $\mathrm{p}$-value) & 0.6706 \\
\hline Fixed effects (time) & YES \\
\hline Fix effects (country) & YES \\
\hline Observations & 578 \\
\hline
\end{tabular}

Notes: $\overline{t \text { statistics in parentheses }{ }^{*} p<0.05,{ }^{* *} p<0.01,{ }^{* * *} p<0} 0.001$.

Continuing with the analysis and considering the existence of a regional energy policy in the EU and the presence of cross-section dependence in the entire panel and in the group of countries that make up this Union (Table 3), a spatial econometric model is estimated, in order to establish the spatial dependence on energy consumption. According to LeSage and Pace [28], spatial dependence reflects a situation in which the values observed in a location or region, for example, observation $i$, depend on the values of its neighbors in nearby places. In other words, it aims to determine the existence of "spills" in the implementation of the energy policy in the period analyzed, taking into account the spatial behavior of the explanatory variables used.

Table 5 shows the results of the Spatial Durbin Model (SDM) [60], which considers the presence of temporal autocorrelation and heteroscedasticity in its estimation.

First, it is observed that the temporal lag of the spatially weighted dependent variable: (L.Wlce) is statistically significant, indicating that energy consumption in Europe not only presents a temporal autoregressive process, but also a spatial one. It is observed that the behavior of energy consumption in a given country depends not only on its past values over time, but also on the consumption level of its neighbors, corroborating the efficiency of the energy policy in the European Union. These results are similar to those of Jiang, Folmer, Ji, and Zhou [49], where the estimation of a spatial panel model for 29 Chinese provinces in the period 2003-2015 showed that the effectiveness of the policy of saving or reducing energy consumption depends significantly on the spatial "spills" between neighboring provinces. 
Table 5. Dynamic SDM model estimation for fixed effects (Only statistically significant variables).

\begin{tabular}{|c|c|}
\hline Variables & SDM \\
\hline \multicolumn{2}{|l|}{ Main } \\
\hline L.Wlce & $\begin{array}{c}0.387^{* *} \\
(3.04)\end{array}$ \\
\hline Spatial & \\
\hline rho & $\begin{array}{l}0.192 * \\
(2.21)\end{array}$ \\
\hline \multicolumn{2}{|l|}{ Variance } \\
\hline sigma2_e & $\begin{array}{c}0.00470 * * * \\
(17.47)\end{array}$ \\
\hline \multicolumn{2}{|l|}{ Wx } \\
\hline Human capital & $\begin{array}{c}-0.138 * * * \\
(-3.91)\end{array}$ \\
\hline Renewable Energy Price & $\begin{array}{c}-0.0446 \text { * } \\
(-2.28)\end{array}$ \\
\hline Value added in industry & $\begin{array}{c}0.223^{*} \\
(2.05)\end{array}$ \\
\hline Value added in services & $\begin{array}{c}-0.381^{* *} \\
(-2.74)\end{array}$ \\
\hline Employment in industry & $\begin{array}{c}-0.520 * * * \\
(-3.42)\end{array}$ \\
\hline Employment in services & $\begin{array}{c}0.703 * \\
(2.49)\end{array}$ \\
\hline Observations & 544 \\
\hline AIC & -1372.3 \\
\hline $\mathrm{BIC}$ & -1307.8 \\
\hline
\end{tabular}

Notes: $t \overline{\text { statistics in parentheses }{ }^{*} p<0.05,{ }^{* *} p<0.01,{ }^{* * *} p}<0.001$.

On the other hand, human capital is statistically significant and of a negative sign, noting that its increase, considering the effects of contiguity and spatial concentration, decreases energy consumption; a $1 \%$ increase in human capital reduces energy consumption by $0.138 \%$. With regard to the oil price, a statistically negative influence on energy consumption in Europe is observed, denoting the presence of negative spillovers in the case of this variable; an increase of $1 \%$ decreases energy consumption by $0.0446 \%$. This result is contrary to what was found by Huang, Du, and Hao [48], where an increase in the energy price generated an increase in energy consumption for the Chinese provinces in the period 2000-2014, in the context of the estimation of a spatial panel.

The analysis of the control variables enables one to observe that the value added in industry and employment in services has a statistically positive relationship with respect to energy consumption, as in the estimation of Table 4. This confirms that the growth of these economy sectors depends significantly on energy consumption. Therefore, a $1 \%$ increase in these two variables increases the value of the dependent variable by $0.223 \%$ and $0.703 \%$, respectively.

These results are similar to those obtained in Jiang, Folmer, Ji, and Zhou [49], Huang, Du, and Hao [48], and Han, Xie, and Fang [50], where an increase in the participation of the secondary sector in the total economic activity generated an increase in energy consumption for the Chinese regions analyzed in the period 2000-2017, in the spatial panel model. However, they are the opposite to those found in Hao and Peng [51], where an increase in this participation was not statistically significant in the variant of the estimated Spatial Durbin Model. Finally, the value added in services and employment in industry are statistically significant and have a negative impact on energy consumption in Europe: An increase of these variables by $1 \%$ causes a reduction in energy consumption in Europe of $0.381 \%$ and of $0.520 \%$, respectively. 


\section{Conclusions and Policy Recommendations}

This study analyzed the effect of human capital and the oil price on the energy consumption of 37 countries of the European continent, belonging and not belonging to the European Union. With the help of explanatory variables and the contribution of temporary dummies and by country, the hypothesis that human capital and the oil price lead to a decrease in energy consumption is verified, both in Europe (Total) and in the European Union (EU) in the panel model for fixed effects. The results show that a variation in the levels of human capital and oil prices of a European country generate inverse changes in energy consumption, so an implication of economic policy suggests improvements in the education system, training, and education of human capital, since it will contribute to the reduction of energy consumption in the poorest European countries.

Regarding the results of the Spatial Durbin Model, it can be observed that the "energy consumption" variable shows a spatial autoregressive process. In addition, the statistical significance of temporal delay also demonstrates the existence of a temporary autoregressive process. In other words, the energy consumption of the European Union in the analyzed period depends not only on its past values, but also on the spatial interaction between the countries analyzed. The oil price, the value added in services, and employment in industry have statistically negative spatial effects, an increase in these variables reduces the energy consumption of the analyzed data panel; unlike the value added in industry and employment in services that have a statistically positive relationship with energy consumption: An increase in these two variables increases energy consumption.

Considering that the effect of the reduction in consumption caused by human capital is higher in the SDM (Table 5), coordination between government agencies responsible for education in Europe is suggested, in order to generate policies aimed at generating positive synergies in the academic results of the countries analyzed, mainly in those countries that are not part of the European Union, which could benefit significantly from the positive spatial externalities of a more efficient educational policy. With regard to production and employment by economic sectors, the implementation of policy measures aimed at energy saving is proposed, that is, to promote an increasingly less energy-dependent production and the development of the renewable energy sector, this due to the fact that even an increase in the employment of services causes an increase in the energy consumption in the countries analyzed. It is likewise recommended to generate incentives that contribute to the promotion of employment and production of the manufacturing industry since it tends to reduce energy consumption, due to the gradual decrease in the use of fossil energies for the productive processes of the developed countries of this part of the world. In this context, it is suggested the implementation of policies aimed at the development of technology services and high added value, which according to the results also contribute to energy saving. One of the limitations of this study is that the country classification was not carried out according to their income level, so as to evaluate the effects of energy consumption based on heterogeneity shown by each country. Finally, among the extensions of the document, it is suggested to extend the period to better analyze the problems related to short panels, and include variables that approximate the effect of environmental policy on the variations of the level of well-being of European countries.

Author Contributions: All authors contributed equally to this work. All authors wrote, reviewed, and commented on the manuscript. All authors have read and approved the final manuscript.

Funding: This research received no external funding.

Conflicts of Interest: The authors declare no conflict of interest.

\section{References}

1. Hao, Y.; Huang, Z.; Wu, H. Do Carbon Emissions and Economic Growth Decouple in China? An Empirical Analysis Based on Provincial Panel Data. Energies 2019, 12, 2411. [CrossRef]

2. Salim, R.; Yao, Y.; Chen, G.S. Does human capital matter for energy consumption in China? Energy Econ. 2017, 67, 49-59. [CrossRef] 
3. Shahbaz, M.; Gozgor, G.; Hammoudeh, S. Human Capital and Export Diversification as New Determinants of Energy Demand in the United States. Energy Econ. 2018, 78, 335-349. [CrossRef]

4. Coers, R.; Sanders, M. The energy-GDP nexus; addressing an old question with new methods. Energy Econ. 2013, 36, 708-715. [CrossRef]

5. Humbatova, S.I.; Qadim-Oglu Hajiyev, N. Oil factor in economic development. Energies 2019, $12,1573$. [CrossRef]

6. Moshiri, S. The effects of the energy price reform on household's consumption in Iran. Energy Policy 2015, 79, 177-188. [CrossRef]

7. Moshiri, S.; Martínez Santillán, M.A. The welfare effects of energy price changes due to energy market reform in Mexico. Energy Policy 2018, 113, 663-672. [CrossRef]

8. Sarkodie, S.A.; Adom, P.K. Determinants of Energy Consumption in Kenya: A NIPALS Approach. Energy 2018, 159, 696-705. [CrossRef]

9. Council and the European Parliament. The Load Sharing Agreement is Found in the Annex of the Commission Communication to the Council and the European Parliament Preparing for the Application of the Kyoto Protocol COM230 Final of 19.05.1999. 1999. Available online: https://ec.europa.eu/clima/sites/clima/files/ets/ docs/com_1999_230_en.pdf (accessed on 19 July 2019).

10. Siksnelyte, I.; Zavadskas, E.K. Achievements of the European Union countries in seeking a sustainable electricity sector. Energies 2019, 12, 2254. [CrossRef]

11. Statistical Review of World Energy. 2017. Available online: https://www.bp.com/content/dam/bp-country/ de_ch/PDF/bp-statistical-review-of-world-energy-2017-full-report.pdf (accessed on 14 July 2019).

12. World Bank. World Development Indicators: Ecuador; World Bank Group: Washington, DC, USA, 2017. Available online: https://datos.bancomundial.org/pais/ecuador (accessed on 14 July 2019).

13. Anselin, L. Spatial Econometrics: Methods and Models; Springer Science \& Business Media: Berlin, Germany, 2013; Volume 4.

14. Kharbach, M.; Chfadi, T. Oil prices and electricity production in Morocco. Energy Strategy Rev. 2018, 22, 320-324. [CrossRef]

15. Rajbhandari, A.; Zhang, F. Does energy efficiency promote economic growth? Evidence from a multicountry and multisectoral panel dataset. Energy Econ. 2018, 69, 128-139. [CrossRef]

16. Carfora, A.; Pansini, R.V.; Scandurra, G. The causal relationship between energy consumption, energy prices and economic growth in Asian developing countries: A replication. Energy Strategy Rev. 2019, 23, 81-85. [CrossRef]

17. Pan, G.; Gu, W.; Wu, Z.; Lu, Y.; Lu, S. Optimal design and operation of multi-energy system with load aggregator considering nodal energy prices. Appl. Energy 2019, 239, 280-295. [CrossRef]

18. Wang, C.; Nie, P. How rebound effects of efficiency improvement and price jump of energy influence energy consumption? J. Clean. Prod. 2018, 202, 497-503. [CrossRef]

19. Sohag, K.; Begum, R.A.; Syed Abdullah, S.M.; Jaafar, M. Dynamics of energy use, technological innovation, economic growth and trade openness in Malaysia. Energy 2015, 90, 1497-1507. [CrossRef]

20. Arbex, M.; Perobelli, F.S. Solow meets Leontief: Economic growth and energy consumption. Energy Econ. 2010, 32, 43-53. [CrossRef]

21. Miller, M.; Alberini, A. Sensitivity of price elasticity of demand to aggregation, unobserved heterogeneity, price trends, and price endogeneity: Evidence from U.S. Data. Energy Policy 2016, 97, 235-249. [CrossRef]

22. Leng Wong, S.; Chia, W.M.; Chang, Y. Energy consumption and energy R\&D in OECD: Perspectives from oil prices and economic growth. Energy Policy 2013, 62, 1581-1590.

23. Yazdan, G.F.; Behzad, V.; Shiva, M. Energy Consumption in Iran: Past Trends and Future Directions. Procedia-Soc. Behav. Sci. 2012, 62, 12-17. [CrossRef]

24. Ing, Y.S.; Liao, H.F.; Huang, K.S. The extended Durbin method and its application for piezoelectric wave propagation problems. Int. J. Solids Struct. 2013, 50, 4000-4009. [CrossRef]

25. Li, B.; Wu, S. Effects of local and civil environmental regulation on green total factor productivity in China: A spatial Durbin econometric analysis. J. Clean. Prod. 2017, 153, 342-353. [CrossRef]

26. Lv, Y.; Chen, W.; Cheng, J. Modelling dynamic impacts of urbanization on disaggregated energy consumption in China: A spatial Durbin modelling and decomposition approach. Energy Policy 2019, 133, 110841. [CrossRef] 
27. Shurui, J.; Jingyou, W.; Lei, S.H.I.; Zhong, M. Impact of Energy Consumption and Air Pollution on Economic Growth An Empirical Study Based on Dynamic Spatial Durbin Model. Energy Procedia 2019, 158, 4011-4016. [CrossRef]

28. LeSage, J.; Pace, R.K. Introduction to Spatial Econometrics; Chapman and Hall/CRC: London, UK, 2009.

29. Akadiri, S.; Bekun, F.V.; Sarkodie, S.A. Contemporaneous interaction between energy consumption, economic growth and environmental sustainability in South Africa: What drives what? Sci. Total Environ. 2019, 686, 468-475. [CrossRef]

30. Bekun, F.V.; Emir, F.; Sarkodie, S.A. Another look at the relationship between energy consumption, carbon dioxide emissions, and economic growth in South Africa. Sci. Total Environ. 2019, 655, 759-765. [CrossRef]

31. Destek, M.A.; Sarkodie, S.A. Investigation of environmental Kuznets curve for ecological footprint: The role of energy and financial development. Sci. Total Environ. 2019, 650, 2483-2489. [CrossRef]

32. Bekun, F.V.; Alola, A.A.; Sarkodie, S.A. Toward a sustainable environment: Nexus between CO2 emissions, resource rent, renewable and nonrenewable energy in 16-EU countries. Sci. Total Environ. 2019, 657, 1023-1029. [CrossRef]

33. Sarkodie, S.A.; Crentsil, A.O.; Owusu, P.A. Does energy consumption follow asymmetric behavior? An assessment of Ghana's energy sector dynamics. Sci. Total Environ. 2019, 651, 2886-2898. [CrossRef]

34. Fang, Z.; Chang, Y. Energy, human capital and economic growth in Asia Pacific countries-Evidence from a panel cointegration and causality analysis. Energy Econ. 2016, 56, 177-184. [CrossRef]

35. Li, K.; Lin, B. Impact of energy technology patents in China: Evidence from a panel cointegration and error correction model. Energy Policy 2016, 89, 214-223. [CrossRef]

36. Huang, B.N.; Hwang, M.J.; Yang, C.W. Causal relationship between energy consumption and GDP growth revisited: A dynamic panel data approach. Ecol. Econ. 2008, 67, 41-54. [CrossRef]

37. Salim, R.A.; Hassan, K.; Shafiei, S. Renewable and non-renewable energy consumption and economic activities: Further evidence from OECD countries. Energy Econ. 2014, 44, 350-360. [CrossRef]

38. Inglesi-Lotz, R.; del Corral Morales, L.D. The Effect of Education on a Country's Energy Consumption: Evidence from Developed and Developing Countries. 2017. Available online: https://ideas.repec.org/p/pre/ wpaper/201733.html (accessed on 14 July 2019).

39. Pablo-Romero, M.D.P.; Sánchez-Braza, A. Productive energy use and economic growth: Energy, physical and human capital relationships. Energy Econ. 2015, 49, 420-429. [CrossRef]

40. Huntington, H.G. Short- and long-run adjustments in U.S. petroleum consumption. Energy Econ. 2010, 32, 63-72. [CrossRef]

41. Valizadeh, J.; Sadeh, E.; Javanmard, H.; Davodi, H. The effect of energy prices on energy consumption efficiency in the petrochemical industry in Iran. Alex. Eng. J. 2018, 57, 2241-2256. [CrossRef]

42. Lee, C.C.; Chiu, Y.B. Modeling OECD energy demand: An international panel smooth transition error-correction model. Int. Rev. Econ. Financ. 2013, 25, 372-383. [CrossRef]

43. Gately, D.; Huntington, H. The Asymmetric Effects of Changes in Price and Income on Energy and Oil Demand. Energy J. 2015, 23, 19-55. [CrossRef]

44. Bentzen, J.; Engsted, T. Short- and long-run elasticities in energy demand. Energy Econ. 2002, 15, 9-16. [CrossRef]

45. Yuan, C.; Liu, S.; Wu, J. The relationship among energy prices and energy consumption in China. Energy Policy 2010, 38, 197-207. [CrossRef]

46. Labandeira, X.; Labeaga, J.M.; López-Otero, X. A meta-analysis on the price elasticity of energy demand. Energy Policy 2017, 102, 549-568. [CrossRef]

47. Jiang, L.; Folmer, H.; Ji, M. The drivers of energy intensity in China: A spatial panel data approach. China Econ. Rev. 2014, 31, 351-360. [CrossRef]

48. Huang, J.; Du, D.; Hao, Y. The driving forces of the change in China's energy intensity: An empirical research using DEA-Malmquist and spatial panel estimations. Econ. Model. 2017, 65, 41-50. [CrossRef]

49. Jiang, L.; Folmer, H.; Ji, M.; Zhou, P. Revisiting cross-province energy intensity convergence in China: A spatial panel analysis. Energy Policy 2018, 121, 252-263. [CrossRef]

50. Han, F.; Xie, R.; Fang, J. Urban agglomeration economies and industrial energy efficiency. Energy 2018, 162, 45-59. [CrossRef]

51. Hao, Y.; Peng, H. On the convergence in China's provincial per capita energy consumption: New evidence from a spatial econometric analysis. Energy Econ. 2017, 68, 31-43. [CrossRef] 
52. Liu, X.; Lin, J.; Hu, J.; Lu, H.; Cai, J. Economic Transition, Technology Change, and Energy Consumption in China: A Provincial-Level Analysis. Energies 2019, 12, 2581. [CrossRef]

53. Pirlogea, C.; Cicea, C. Econometric perspective of the energy consumption and economic growth relation in European Union. Renew. Sustain. Energy Rev. 2012, 16, 5718-5726. [CrossRef]

54. Beşir, L.; Aldea, A. Assessing eco-efficiency of countries in the context of renewable and non-renewable energy consumption: A non-parametric partial frontier perspective. Econ. Comput. Econ. Cybern. Stud. Res. 2019, 53, 131-148.

55. Hausman, J.A. Specification tests in econometrics. Econom. J. Econom. Soc. 1978, 46, 1251-1271. [CrossRef]

56. Wooldridge, J.M. Econometric Analysis of Cross Section and Panel Data; MIT Press: Cambridge, MA, USA, 2002.

57. Greene, W.H. Econometric Analysis; Pearson Education: London, UK, 2003.

58. Wang, Q.; Su, M.; Li, R.; Ponce, P. The effects of energy prices, urbanization and economic growth on energy consumption per capita in 186 countries. J. Clean. Prod. 2019, 225, 1017-1032. [CrossRef]

59. Wooldridge, J.M. Introducción a La Econometría. Un Enfoque Moderno, 4a ed.; Cengage Learning Editores: México DF, México, 2010.

60. Durbin, J.; Watson, G.S. Testing for serial correlation in least squares regression III. Biometrika 1971, 58, 1-9. [CrossRef]

(C) 2019 by the authors. Licensee MDPI, Basel, Switzerland. This article is an open access article distributed under the terms and conditions of the Creative Commons Attribution (CC BY) license (http://creativecommons.org/licenses/by/4.0/). 